U.S. Department of the Interior

U.S. Geological Survey

\title{
Lahar Hazards at Agua Volcano, Guatemala
}

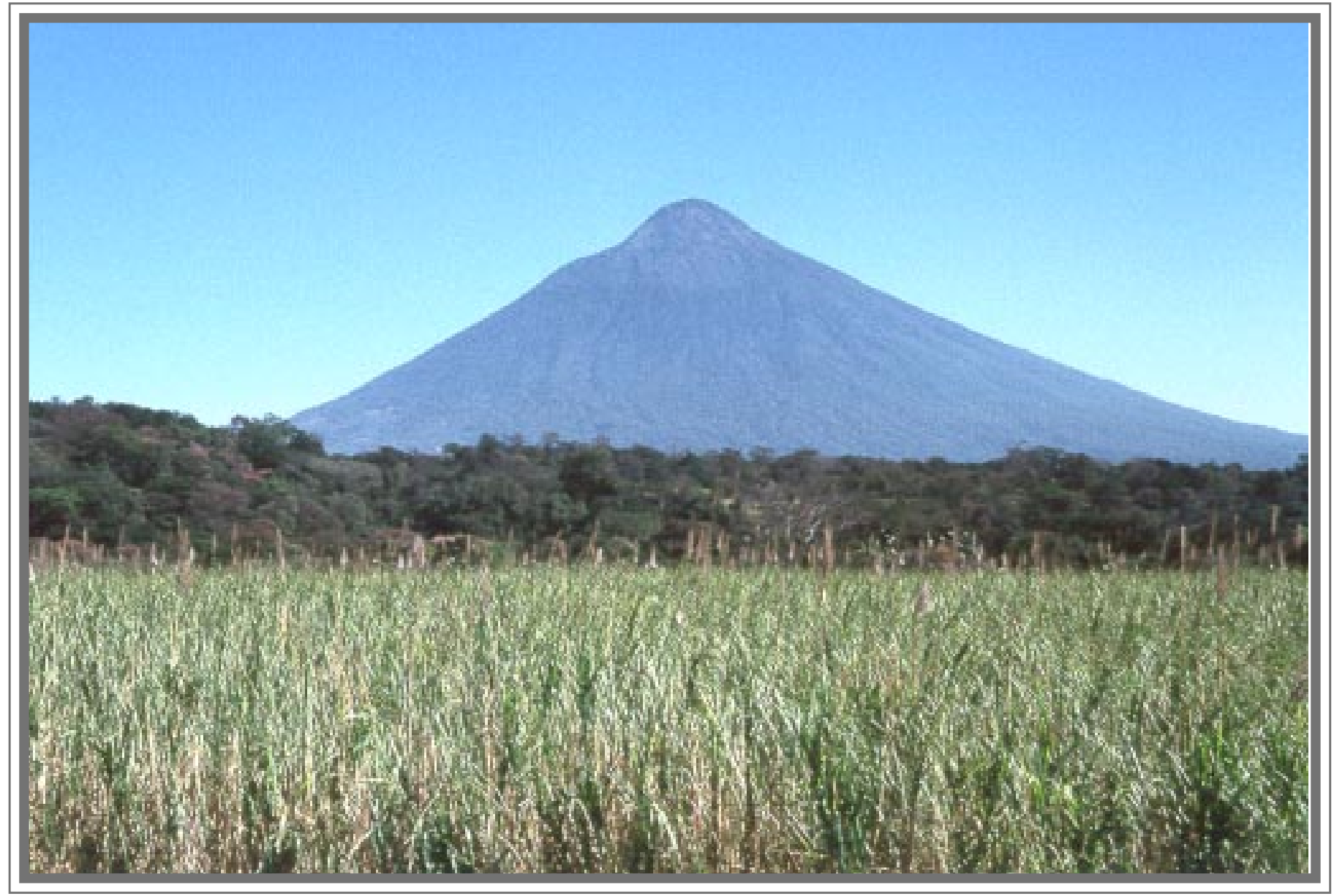

Open-File Report 01-432 


\section{Cover photograph}

Agua volcano viewed from the west. (Photo by J.W. Vallance). 


\section{Lahar-Hazards at Agua Volcano, Guatemala}

By S.P. Schilling, J.W. Vallance, O. Matías, and M.M Howell

U.S. GEOLOGICAL SURVEY

Open-File Report 01-432 


\section{U.S. DEPARTMENT OF THE INTERIOR \\ Gale Norton, Secretary}

U.S. GEOLOGICAL SURVEY

Charles G. Groat, Director

This report is preliminary and has not been reviewed for conformity with U.S. Geological Survey editorial standards. Any use of trade, product, or firm names is for descriptive purposes only and does not imply endorsement by the U.S. Government.

For additional information write to:

Copies of this report can be purchased from:

Scientist-in-Charge

U.S. Geological Survey

1300 SE Cardinal Court, Bldg. 10

Vancouver, WA 98683

(360) 993-8900

FAX: (360) 993-8980
U.S. Geological Survey

Information Services

P.0. Box 25286

Denver, CO 80225

(303) 202-4210 


\section{CONTENTS}

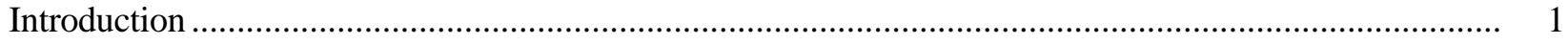

Debris Avalanches, Landslides, and Lahars .................................................................................... 4

Future Landslides and Lahars at Agua Volcano .............................................................................. 5

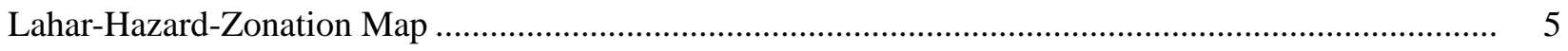

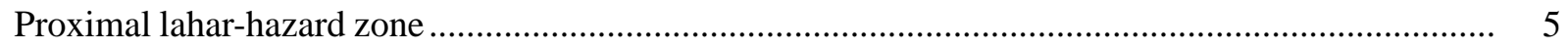

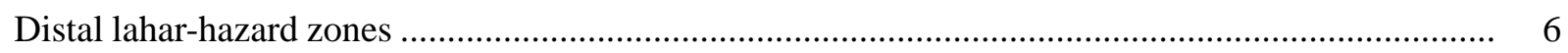

Hazard Forecasts and Warnings .......................................................................................... 6

Protecting Communities and Citizens from Lahar Hazards ................................................................. 6

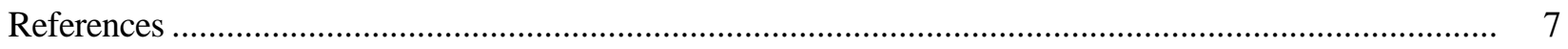

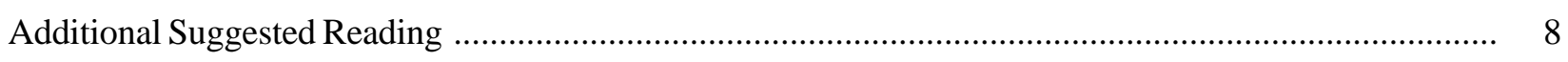

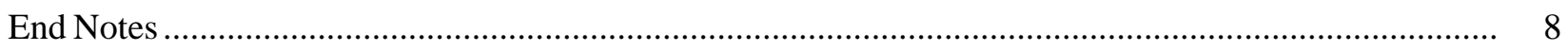

\section{PLATE [In pocket]}

1. Lahar hazards of Agua volcano, Guatemala..Proximal and distal hazard zones from lahars at Agua volcano.

\section{FIGURES}

1. Locations of major cities and significant Quaternary volcanoes in Guatemala including Agua volcano

2 Schematic map showing the areal extent of and two cross-sections for the Casita, Nicaragua, debris flow of 1998 


\title{
Lahar Hazards at Agua Volcano, Guatemala
}

\author{
By S.P. Schilling, J.W. Vallance, 0. Matías ${ }^{1}$, and M.M Howell
}

\section{INTRODUCTION}

At $3760 \mathrm{~m}$, Agua volcano towers more than $3500 \mathrm{~m}$ above the Pacific coastal plain to the south and $2000 \mathrm{~m}$ above the Guatemalan highlands to the north (figure 1). The volcano is within 5 to 10 kilometers $(\mathrm{km})$ of Antigua, Guatemala and several other large towns situated on its northern apron. These towns have a combined population of nearly 100,000 . It is within about $20 \mathrm{~km}$ of Escuintla (population, $c a .100,000$ ) to the south. Though the volcano has not been active in historical time [1] (numerals in brackets refer to end notes in the report), or about the last 500 years, it has the potential to produce debris flows (watery flows of mud, rock, and debris-also known as lahars when they occur on a volcano) that could inundate these nearby populated areas.

In late October and early November 1998, torrential rains of Hurricane Mitch caused numerous slope failures in Central America, the most catastrophic of which occurred at Casita volcano, Nicaragua on

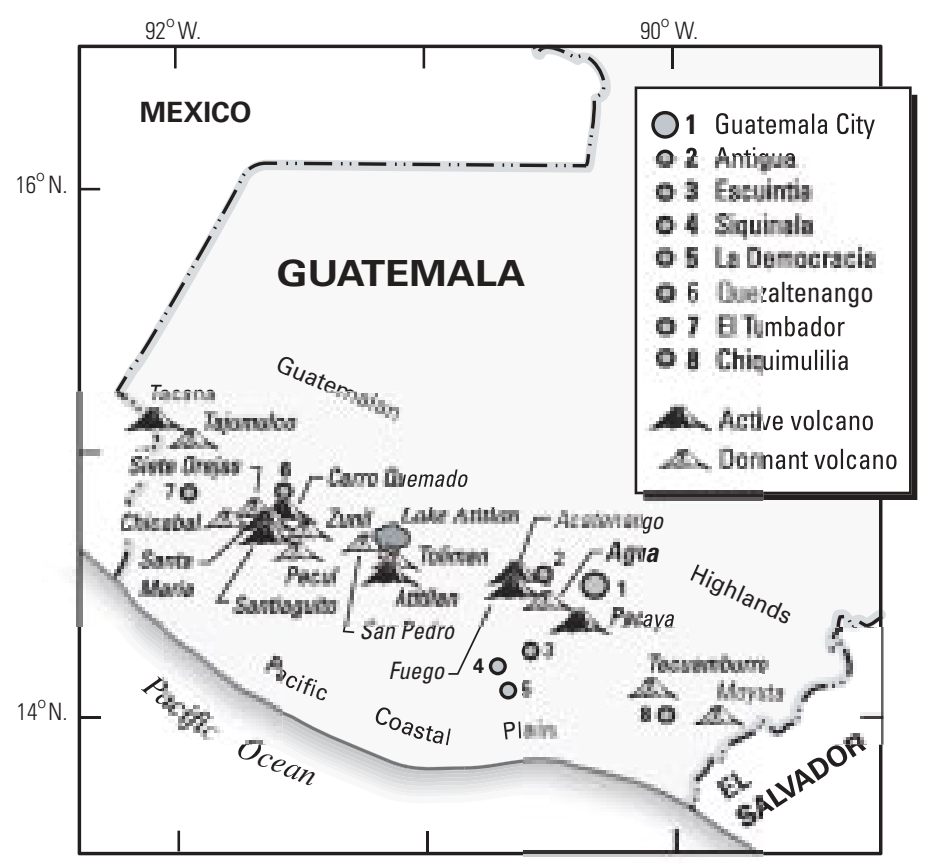

Figure 1. Locations of major cities and significant Quaternary volcanoes in Guatemala including Agua volcano adapted from Vallance et al. (1995). Circles indicate major cities, solid triangles indicate active volcanoes and open triangles indicate dormant volcanoes. Atitlán is a large silicic caldera.

\footnotetext{
${ }^{1}$ Instituto sismología, vocanología, meteorología, y hidrología (INSIVUMEH), Guatemala.
} 
October 30, 1998. At Casita, five days of heavy rain triggered a 1.6-million-cubic-meter rock and debris avalanche that generated a 2- to 4-millioncubic-meter debris flow that swept down the steep slopes of the volcano, spread out across the volcano's apron, destroyed two towns, and killed more than 2500 people [2]. The avalanche did not dam the upper drainages or impound water. Rather, it appears that the Casita debris flow evolved directly as the avalanche moved down slope [2].

On October 30, 1998 between 10:30 and 11:00 a.m., residents south of Casita heard a roaring noise like helicopters or thunder. Some thought an earthquake was occurring. Three to five minutes thereafter, a wave of muddy debris $1.0-1.3 \mathrm{~km}$ wide and an average of $3.5 \mathrm{~m}$ deep destroyed all traces of two towns (figure 2). Observations by survivors record an enormous flood on the slopes of the volcano and a wall of mud on the volcano apron. A person on the volcano slopes saw a "black curtain of water with trees." On the apron of the volcano where the flow spread out, survivors describe the flow as- "an infernal wave of mud, rocks, and trees," or "enormous mass of mud." [2]. The debris flow moved about $10 \mathrm{~km}$ from its source. It also generated floods that moved an additional $10 \mathrm{~km}$ downstream, destroying roads and bridges and inundating homes.

No large debris flows occurred at Agua volcano during Hurricane Mitch, but historical accounts indicate that such events have occurred there in the past. On September 11, 1541, heavy rains caused a debris flow that inundated Cuidad Vieja (plate 1), killed more than 600 people, and destroyed the town [1]. Cuidad Vieja was the capitol city of Guatemala in 1541. After the destruction of Cuidad Vieja, the capital moved to Antigua Guatemala. The following eyewitness accounts record this event.

Este año a sido de muchas aguas y habiento llovido jueves y viernes y sábado con mucho viento y no mucha agua el dicho lavada serían como es dicho dos horas de noche. Vino muy gran tormenta de agua de lo alto del volcán (Agua) que esta encima de la ciudad fue tan súpito que no ... para poder remediar las muertes y danos que sucedieron fue tanta la tormenta de la piedra que trago por delante el agua y la mucha madera y árboles que los que lo uimos estábamose admirados entro por la casa de la del Adelantado don Pedro Alvarado que aya gloria que llevo todas las paredes y tezado como esetaba mas de en tire de ballesta...(Marroquín) [1].

El memorabilisimo [suceso] de 11 de septiembre de 1541, que totalmente arruinó la ciudad vieja de Guatemala ... continuándose por muchos días, que a no prevenir al aviso de un ruidoso estruendo como por debajo de tierra, hubieran causado los terremotos, que hubo después de la ruina de la ciudad, aun más muertas, que en las que en ella hubo, siendo en número de más de seiscientas personas. Bastantemente expresan las juntas, y funciones de Cabildo esta tribulación; pues en todas las que se tuvieron para conseguir mudar la ciudad, dicen, estar casi continuamente temblando la tierra (Vázquez 1937:1:154) [1].

\section{[English translation:]}

This has been a year of much rain, and having been raining Thursday, Friday and Saturday, with strong winds and not much water, the mentioned "lavada" [wash, means heavy rain or the debris flow?] happened two hours into the night. A great storm of water came from atop the volcano (Agua) which is above the city, it was so sudden that [we] did not ... prevent the deaths and damages that happened; the stone storm [debris flow] was so huge that it swallowed the water in front of it, and much wood and trees, those who saw it were impressed, it entered through the house of the "Adelantado" don Pedro Alvarado, and it took away all the walls and the roof ...(Marroquin) [1].

The well remembered [event] of September 11th, 1541, that totally destroyed old Guatemala City [this first capital is now named Cuidad Vieja] ... 


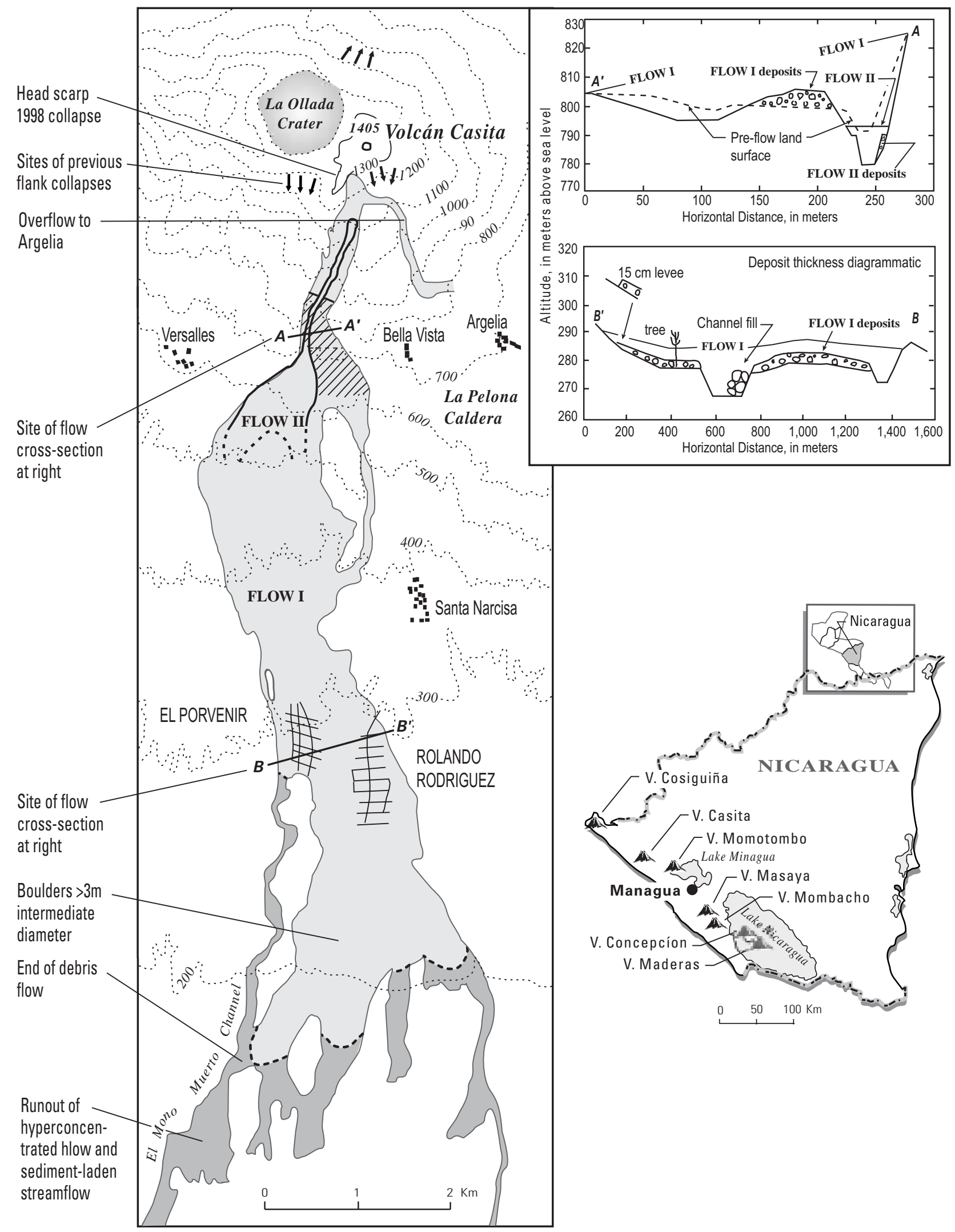

Figure 2. Schematic map showing the areal extent of and two cross-sections for the Casita, Nicaragua debris flow of 1998 adapted from Scott $e t$ al. (in press). 
lasting many days. Were it not for the noisy uproar underneath the earth that the earthquakes caused, many more deaths would have taken place than those that happened there, a number greater than six hundred people. The meetings and functions of the town Council state this tribulation, since during each meeting they had to achieve the move of the City, they say, the earth was constantly trembling. (Vázquez 1937:1:154) [1].

Although many have suggested that the 1541 debris flow resulted from a crater-lake breakout the accounts above and others in reference note [1] suggest that the 1541 debris flow at Agua was remarkably similar to the 1998 debris flow at Casita. In each case, the event occurred in the latter half of the rainy season, when the ground was water saturated. In each case, several days of heavy rain triggered a landslide, which in turn generated a debris flow. In each case, survivors reported that the ground shook immediately prior to the arrival of the debris flow, and many people mistook the event for an earthquake. In each case, the debris flow destroyed population centers on the apron of the volcano.

In prehistoric time, Agua has erupted explosively to form widespread ash-fall deposits (called tephra), hot ash flows (called pyroclastic flows) and lava flows. Although the volcano has erupted numerous times during the past 80,000 years, the most recent eruptions presently dated are more than 10,000 years ago [1]. If such eruptions were to occur now, many people and costly infrastructure would be at risk. In the aftermath of a voluminous eruption of ash or pyroclastic flows, volcanic debris flows would certainly occur during the rainy seasons.

This report describes the hazards of landslides and lahars in general, and discusses potential hazards from future landslides and lahars at Agua volcano in particular. The report also shows, in the accompanying lahar-hazard-zonation map, which areas are likely to be at risk from future landslides and lahars at Agua. A broader volcano-hazard assessment of the volcano is in progress [1].

\section{DEBRIS AVALANCHES, LANDSLIDES, AND LAHARS}

Slope failure on a volcano can generate a rapidly moving landslide called a debris avalanche. Small-volume debris avalanches typically travel only a few kilometers from their source, but large-volume debris avalanches can travel tens of kilometers from a volcano. Debris avalanches destroy everything in their paths and can leave deposits of 10 meters thick or more on valley floors.

Lahars, also called mudflows and debris flows, are masses of mud, rock, and water that look much like flowing concrete. They occur when water mobilizes large volumes of loose mud, rock, and volcanic debris. Commonly, landslides and debris avalanches will incorporate enough water to form lahars. Lahars, like floods, inundate floodplains and structures in low-lying areas. They can travel many tens of kilometers down valleys at speeds of tens of kilometers per hour. Lahars destroy or damage everything in their paths through burial or impact. Lahars follow river valleys and leave deposits of muddy sand and gravel that can be several meters thick. They are particularly hazardous because they travel farther from a volcano than any other hazardous phenomenon except tephra, and they affect stream valleys where human settlement is usually greatest. In some instances, lahars clog channels or block tributaries so that water collects behind the blockage. The impounded water can spill over the blockage and generate floods that move down valley. Breaching of such blockages can occur within hours, months, or even years after impoundment.

Like floods, lahars range greatly in size. The smallest lahars occur most frequently (perhaps every few years), whereas the largest recur on the order of centuries to millennia. The amount of water and loose volcanic debris entrained determines lahar size. Eruptions, like historical examples at nearby Fuego Volcano, can deposit millions of cubic meters of sediment into channels that when mixed with water during subsequent rains causes lahars [3].

Landslides and lahars can cause problems long after the original eruptive or other disturbance. 
Once lahars fill stream channels with sediment, the streams begin to erode new paths. The new stream channels can be highly unstable and shift rapidly as sediment is eroded and moved farther down valley.

Also, because stream channels are clogged with sediment, they have less ability to convey water and thus are more susceptible to smaller-magnitude floods.

\section{FUTURE LANDSLIDES AND LAHARS AT AGUA VOLCANO}

Like neighboring Fuego and Acatenango volcanoes, Agua can erupt explosively to produce pyroclastic flows and widespread tephra falls, though the lack of historical volcanism of this type suggests that the probability of explosive eruptions at Agua is less than at Acatenango and much less than at Fuego [1, 3]. At Fuego such eruptions occur once every several years; at Acatenango they occur about once every thousand years; but at Agua none are documented in the last ten thousand years. The ash and loose debris produced by an eruption would surely cause lahars when mixed with water from rains during the rainy season. Small volcanic earthquakes, steam explosions and deformation of the crater area would be likely to precede pyroclastic eruptions at Agua volcano

Because eruptions are likely to be infrequent at Agua, landslides and debris flows during torrential rainstorms are the most likely threats to nearby people and infrastructure [1]. Because there is less loose, easily erodible volcaniclastic material on the slopes of Agua than on Fuego volcano, debris flows having this origin are less likely than at Fuego. These phenomena, like those at Casita, Nicaragua and at Agua in 1541, are most apt to occur during unusually intense rain. They are especially likely after long periods of rain toward the end of the rainy season.

\section{LAHAR-HAZARD-ZONATION MAP}

The accompanying lahar-hazard-zonation map (plate 1) shows areas that could be affected by future lahars at or near Agua volcano. Individual lahars typically affect only part of a hazard zone.
The location and size of an affected area will depend on local conditions, like the volume of material involved, and the character of an eruption, if any.

Potentially hazardous areas around Agua volcano include proximal lahar-hazard zones and distal lahar-hazard zones. Distal lahar-hazard zones are subdivided further on the basis of their relative degree of hazard. Hazard-zone boundaries derive from three main factors. First, there are the magnitudes of lahars known to have occurred at the volcano, as inferred from historical accounts and prehistoric deposits. Second, an empirical model calibrates lahar-inundation limits on the basis of lahars of known volume that have occurred at other volcanoes. Third, we apply our experience and judgment derived from past experience with events of a similar nature at other volcanoes.

Although sharp boundaries delineate each hazard zone, the limit of the hazard does not end abruptly at the boundaries. Rather, the hazard decreases gradually as distance from the volcano increases and decreases rapidly with increasing elevation above valley floors. Areas immediately beyond distal hazard zones are not free of risk because the hazard limits can only approximately be located, especially in areas of low relief. Many uncertainties about the source, size, and mobility of future lahars preclude precise location of the hazard-zone boundaries.

Users of our hazard map should be aware that we have not simulated all hazardous landslide and lahar scenarios. The edifice of Agua volcano is steep, incised, and partly affected by hydrothermal weakening of the rock. For this report, we selected prominent channels directed toward populous areas in order to define the most significant zones of inundation from lahars of various volumes. Other channels for which we have not modeled lahar inundation are not necessarily devoid of lahar hazard. Landslides and lahars from other unmapped channels could also threaten life and property.

\section{Proximal lahar-hazard zone}

The proximal lahar-hazard zone includes areas immediately surrounding Agua volcano, and 
extends about 5 kilometers outward from the summit depending upon local topography (plate 1) [4]. This zone delineates areas where lahars originate. During periods of volcanic unrest or during an eruption, this area should be evacuated because events can occur too quickly for humans to escape harm. Avalanches and lahars will originate in the proximal area, and deposits from small slides and flows may be restricted to this zone. However, large debris avalanches and lahars will travel away from the volcano and flow onto adjacent slopes. The extent of inundation from these larger lahars is the basis for defining distal lahar-hazard zones.

\section{Distal lahar-hazard zones}

An automated empirical technique calibrated with data from other volcanoes [5] estimates potential areas of inundation from lahars of various volumes. For each channel analyzed, we define four nested hazard zones that depict anticipated inundation by hypothetical "design" lahars having different volumes. The largest design lahar reflects our estimate of the largest probable lahar generated on the steep slopes of Agua volcano (plate 1) [5]. The intermediate and smallest design lahars are more typical lahar volumes. Lahars of the largest sizes have occurred historically at Agua and would be likely after an eruption or during severe rainstorms.

Large lahars are less likely to occur than small lahars. Thus, the nested lahar-hazard inundation zones show that the likelihood of lahar inundation decreases as distance from the volcano and elevation above the valley floors increases. Lahars of all designated sizes could form on the volcano's slopes if unusually intense rainstorms occur. The largest design lahar (plate 1) is based on the size of the largest lahar that occurred during Hurricane Mitch at Casita, Nicaragua. An intense storm, like Hurricane Mitch, would not invariably trigger lahars as large as the one at Casita. Smaller lahars may occasionally result from heavy rains that normally occur each year during the rainy season of May to November.

In general, lahar-hazard zones extend 10 to 25 kilometers from the summit crater (plate 1). Local topography plays a large role in controlling lahar travel distance. Lahars of a given volume will move considerably greater distances southward from the volcano than northward because the southern flank of the volcano drops steeply down to the coastal plain whereas northern slopes intersect the Guatemalan Highlands. Despite their relatively short runout distances, even the smallest lahars moving northward can be devastating because of nearby large population centers in that direction.

\section{HAZARD FORECASTS AND WARNINGS}

It is difficult, if not impossible, to predict the precise occurrence of landslides and lahars triggered by earthquakes or torrential rains. However, generally hazardous conditions that favor formation of landslides and lahars can be recognized. Forecasts for very heavy rainfall, which commonly trigger flood warnings, can serve as indicators of conditions favorable for landslides and lahars. When Agua volcano erupts again, it is likely to disperse tephra fall on its flanks. Subsequent erosion of that tephra can generate lahars similar to or larger than those that have occurred in historical time. In this case, the eruption of the volcano can serve as a warning that conditions are favorable for lahar formation, and the distribution of tephra fall can indicate which flanks are more likely to be affected. However, government officials and the public need to realize that potentially lethal events can occur in the lahar hazard zones with little or no warning.

\section{PROTECTING COMMUNITIES AND CITIZENS FROM LAHAR HAZARDS}

Communities and citizens must plan ahead to mitigate the effects of future landslides and lahars from Agua volcano. Long-term mitigation efforts might include using information about lahar and other volcano hazards contained in plate 1 when making decisions about land use and siting of critical facilities and development. Future development should avoid areas judged to have an unacceptably high risk. 
Depending on the distance from the volcano, the hazard zones depicted on the map are areas that will be affected within a few minutes to about one hour after the onset of a lahar. Beyond 10 kilometers from the volcano's summit escape may be possible if people are given sufficient warning. Within 10 kilometers of the volcano lahars may happen too quickly to provide effective warning. Therefore, citizens must learn to recognize for themselves hazardous conditions that favor formation of landslides and lahars.

Because landslides and lahars can occur without warning, suitable emergency plans for dealing with them should be made in advance. Although it is uncertain when landslides and lahars will occur again at Agua volcano, public officials need to consider issues such as public education, communications, and evacuations as part of a response plan. Emergency plans already developed for floods may apply to some extent, but may need modifications. For inhabitants in low-lying areas a map showing the shortest route to high ground would be helpful.

Knowledge and advance planning are the most important items for dealing with landslide and lahar hazards. Especially important is a plan of action based on the knowledge of relatively safe areas around homes, schools, and workplaces. Lahars pose the biggest threat to people living or recreating along channels that drain Agua volcano. The best strategy for avoiding a lahar is to move to the highest possible ground. A safe height above river channels depends on many factors including the size of the lahar, distance from the volcano, and shape of the valley. For areas beyond about 8 kilometers from the summit of the volcano, all but that largest lahars will rise less than about 10 meters above river level. Landslides and lahars from Agua volcano will happen again, and the best way to cope with these events is through advance planning in order to mitigate their effects.

\section{REFERENCES}

Bonis, S.B. and Salazar, O, 1973, The 1971 and 1973 eruptions of Volcán de Fuego, Guatemala, and some socio-ecoonomic considerations for the volcanologist: Bulletin Volcanologique, v. 37, p. 394-400.
Davies, D.K., Querry, M.W. and Bonis, S.B., 1978, Glowing avalanches from the 1974 eruption of the volcano Fuego, Guatemala: Geological Society of America Bulletin, v.89, p. 369-384.

Feldman, L., 1993, Mountains of Fire Lands that Shake: Labyrinthos, Culver City, CA, 295 p.

Iverson, R.M., Schilling, S.P., and Vallance, J.W., 1998, Objective delineation of lahar-hazard zones downstream from volcanoes: Geological Society of America Bulletin, v. 110, p. 972-984.

Kerle, N., in press, Volume estimation of the 1998 flank collapse at Casita volcano, Nicaragua-a comparison of photogrammetric and conventional techniques: Earth Surface Processes and Landforms

Kerle, N., and van Wyk de Vries, B., 2001, The 1998 debris avalanche at Casita volcano, Nicaraguainvestigation of structural deformation as the cause of slope instability using remote sensing: Journal of Volcanology and Geothermal Research, v. 105 , p. 43-63.

Scott, K.M., Vallance, J.W., Kerle, N, Macías, J.L., Strauch, W., Devoli, G., in press, Catastrophic, precipitation-triggered lahar at Casita volcano, Nicaragua-Flow transformations, flow bulking, and future mitigation stratigies.

Sheridan, M.F., Bonnard, C., Carreno, R., Siebe, C., Strauch, W., Navarro, M., Calero, J.C., and Trujillo, N.B., 1999, Report on the 30 October 1998 rockfall/debris avalanche and breakout flow of Casita volcano, Nicaragua, triggered by Hurricane Mitch: Landslide News, n. 12, p. 2-4.

Vallance, J. W., Siebert, L., Rose, W. I., Girón, J, and Banks, N. G., 1995, Edifice collapse and related hazards in Guatemala: J. Volcanol. and Geotherm. Res., v. 66, p. 337-355.

Vessel, R.K. and Davies, D.K., 1981, Nonmarine sedimentation in an active fore arc basin, SEPM Special Publication no. 31, p. 31-45. 


\section{ADDITIONAL SUGGESTED READING}

Blong, R.J., 1984, Volcanic hazards: Academic Press, Orlando, $424 \mathrm{p}$.

Tilling, R.I., ed., 1989, Volcanic hazards: Short course in geology, v. 1, American Geophysical Union, Washington, D.C., 123 p.

Vallance, J.W. 2000, Lahars: in Sigurdsson, H., Houghton, B., McNutt, S., Rymer, H., and Stix, J., Encyclopedia of Volcanoes, Academic Press, San Diego, p. 601-616.

\section{END NOTES}

[1] Information about the 1541 debris flow that destroyed Cuidad Vieja derives from Feldman (1993). Other geologic data upon which this report is based come chiefly from the unpublished work of Otoniel Matías.

[2] Information about the Casita flow derives from Sheridan et al. (1999), Kerle and Van Wyk de Vries (2001), Kerle (in press), and Scott et al. (in press).

[3] Eruptions of Fuego are described in Bonis and Salazar (1973), Davies et al. (1978), and Vessel and Davies (1981).
[4] The maximum extent of the proximal laharhazard zone derives from the formula $\mathrm{H} / \mathrm{L} \approx 0.5$, in which $\mathrm{H}$ is the elevation difference between the summit of Agua and the hazard boundary line and $\mathrm{L}$ is the horizontal distance from the center of the summit crater to the hazard boundary line (see, for example, Iverson et al., 1998). The steep slopes within the proximal zone are the likely source of future lahars. More gentle slopes outside the proximal zone are areas where lahars will funnel into valleys, travel downstream, and spread out on alluvial fans.

[5] We constructed lahar-hazard zones by choosing design-lahar volumes of 500,000; 1,000,000; $2,000,000 ; 4,000,000$ cubic meters. We then modeled a lahar for each volume using the repeatable empirical model and digital cartographic technique described in Iverson et al. (1998). The model requires the choice of a reasonable range of volumes for each volcano. It then uses these volumes to compute average cross-sectional areas and areas of inundation for each modeled lahar. The GIS based computer program, LAHARZ (Iverson et al., 1998) then calculates the extent of inundation downstream in each drainage that heads on the volcano. 

